\title{
Structure of cytotoxic associated antigen A protein of Helicobacter pylori from Bali and Lombok isolates of Indonesia
}

\author{
Hamong Suharsono ${ }^{1}$ (D), Dewa Nyoman Wibawa², Zainul Muttaqin ${ }^{3}$ and Kadek Karang Agustina ${ }^{4}$ (i)
}

1. Laboratory of Biochemistry, Faculty of Veterinary Medicine, Udayana University, Denpasar, Indonesia; 2. Internal Medicine Laboratory, Faculty of Medicine Udayana University, Denpasar, Indonesia; 3. Biomedical Research Unit, West Nusa Tenggara General Hospital, Lombok, Indonesia; 4. Department of Veterinary Public Health, Faculty of Veterinary Medicine Udayana University, Denpasar, Indonesia.

Corresponding author: Hamong Suharsono, e-mail: hamong@unud.ac.id

Co-authors: DNW: dewa_wibawa@unud.ac.id; ZM: za_taq@yahoo.com; KKA: k.agustina@unud.ac.id Received: 31-12-2019, Accepted: 21-05-2020, Published online: 13-07-2020

doi: www.doi.org/10.14202/vetworld.2020.1319-1326 How to cite this article: Suharsono H, Wibawa DN, Muttaqin Z, Agustina KK (2020) Structure of cytotoxic associated antigen A protein of Helicobacter pylori from Bali and Lombok isolates of Indonesia, Veterinary World, 13(7): 1319-1326.

\begin{abstract}
Background and Aim: Helicobacter pylori is a well-known zoonotic agent with worldwide distribution. In Indonesia, only one report regarding the variation within the cytotoxic associated antigen A (CagA) protein of $H$. pylori has been described in the literature, which was conducted in Manado, South Sulawesi. There remains no report concerning the structure of this protein, particularly for the Bali and Lombok isolates. The objective of this study was to investigate the diversity of H. pylori CagA amino acid sequences of Bali and Lombok isolates, to predict their molecular structures and conduct toxicity examination of CagA on gastric cells.
\end{abstract}

Materials and Methods: A total of 36 samples were used in equal proportions for each pathologic condition. DNA extraction was performed to subculture H. pylori Bali isolates. The amplification of the CagA $3^{\prime}$ variable region was carried out using the primers P1 (5'-GATAACAGGCAAGCTTTTTGAGG-3') and P2 (5'-CTGCAAAAGATTGTTTGGCAG-3'). The W2, W9, and W35 fragments were selected as a representation of $H$. pylori Bali isolates, which were modeled through the threading modeling approach using I-TASSER.

Results: According to the 12 CagA sequences obtained and phylogenetic analyses, the H. pylori strain originating from Bali can be grouped within the East Asian genotypes and is identical to the Lombok strain. In addition, the Bali isolates are phylogenetically more closely related to Southeast Asian strains, particularly the Filipino strain. The relationship between degree of inflammation induced and CagA-positive infection was not statistically significant.

Conclusion: The structure of the H. pylori Bali isolate is identical to that of Lombok isolate, which belongs to the same group of East Asian genotypes, and bacterial virulence is not related to structure.

Keywords: Bali, cytotoxic associated antigen A, Helicobacter pylori, Lombok, structure, virulence.

\section{Introduction}

Helicobacter pylori was first reported to cause infection within human gastric mucosa in 1983 [1]. This was followed by the discovery of other strains of $H$. pylori in the gastric mucosa of various animals, including: Helicobacter muridarum in mice, Helicobacter felis in cats, Helicobacter nemestrinae in squirrels, and Helicobacter canis in dogs [2,3]. It is estimated that more than half of the world's population have been infected by this microaerophilic organism [4], with a variety of prevalence among industrialized and developing countries. In Indonesia, the prevalence of $H$. pylori infection is approximately $53.8 \%$ [5]. A similar result was reported in Mataram, Lombok where $\sim 53.4 \%$ of blood donors tested positive

Copyright: Suharsono, et al. Open Access. This article is distributed under the terms of the Creative Commons Attribution 4.0 International License (http://creativecommons.org/licenses/ by/4.0/), which permits unrestricted use, distribution, and reproduction in any medium, provided you give appropriate credit to the original author(s) and the source, provide a link to the Creative Commons license, and indicate if changes were made. The Creative Commons Public Domain Dedication waiver (http:// creativecommons.org/publicdomain/zero/1.0/) applies to the data made available in this article, unless otherwise stated. for anti-H. pylori antibodies [6]. This data were supported by Soemohardjo et al. [7], in which $H$. pylori isolates were detected within gastric tissue of $\sim 42.9 \%$ of patients through polymerase chain reaction (PCR) method. Clinical manifestation of $H$. pylori colonization within the stomach allegedly exhibits a strong correlation with genotype or genetic variation of the pathogenic bacteria [8]. Researchers have identified several DNA sequences associated with gastric cancer, for example: The DNA motif (AATAAGATA) on the 5 ' region of cytotoxic associated antigen A (CagA), and the repeated region on the 3' end of CagA within the East Asian subtype. In addition, it was found that the phylogenetic origins of bacterial strains also affect the carcinogenic potential of $H$. pylori infection [9].

The most important virulence factors related to H. pylori infection are expression of the $\operatorname{CagA}$ and vacuolating cytotoxic antigen $(\mathrm{VacA})$ genes, as well as the urease enzyme [10]. H. pylori is known to be one of the most genetically diverse microorganisms [11] and was initially divided into two strains: The virulent strain one that produces CagA and VacA proteins, and the non-virulent strain two which does not 
produce these two toxin proteins [12,13]. Following the identification of a variant allele within CagA at the C-terminal of the protein, $H$. pylori was categorized into East Asian and Western strains. The East Asian strain is predominantly found in Japan, China, and South Korea, whereas the Western strain is common to the United States, Europe, and Australia [4]. At the protein level, Covacci et al. [14] reported that a protein with molecular weight of $128 \mathrm{kDa}$ is associated with the incidence of cytotoxicity and peptic ulcer. Moreover, analysis of a variant of the CagA 5' region resulted in significant correlation with the origin and type of gastric disease that occurred [15].

The CagA protein influences cell activity through alteration of host cell signaling pathways, particularly concerning the presence of the EPIYA amino acid sequence located in the $\mathrm{C}$-terminal of CagA protein consisting of Glu-Pro-Ile-Tyr-Ala - with the tyrosine residue serving as the phosphorylation site. There exist several reduplications of different motifs within the $\operatorname{Cag} A$ gene, including EPIYA-A, -B, -C, and -D. EPIYA-A and EPIYA-B are always present in CagA-positive cases. However, the numbers and arrangement of the two other segments vary according to bacterial strain and its pathogenicity. Segments categorized as type EPIYA-A, $-\mathrm{B}$, and $-\mathrm{D}$ are present in the East Asian strain found in Central Asia, East Asia, and North America and have been reported to be highly associated with increased incidence of gastric cancer. Meanwhile, the western strain consists of EPIYA-A, -B, and -C motifs and can be found in Western and Middle Eastern countries, where motif C may have been duplicated several times and differs from one geographical region to another [16].

Studies conducted in several countries such as Turkey, the United States, and Japan showed that variation in CagA-EPIYA is associated with the occurrence of gastric pathology. In Indonesia, there has been only one report regarding variation of the $H$. pylori CagA protein, which was conducted in Manado, South Sulawesi; the incidence, however, was exceptionally low $[17,18]$ within Lombok isolates. Toxicity of CagA is determined by the molecular structure of the C-terminal of the protein. The stronger it binds to the MAP kinase SHP2 [19], the more toxic effects may be elicited.

The objective of this study was to investigate the diversity of $H$. pylori CagA amino acid sequences of Bali and Lombok isolates, to predict their molecular structures and conduct toxicity examination of CagA on gastric cells.

\section{Materials and Methods}

\section{Ethical approval}

This research was approved by the Animal Ethics Committees of The Faculty of Veterinary Medicine at Udayana University, Bali (Ref. No. 1167/UN14.2.9/ PD/2019).

\section{Samples}

The study was conducted from April to May 2019 at the Sanglah Hospital and involved a total of
36 subjects; the samples were collected from patients who met the inclusion criteria by obtaining tissue samples from gastric body and antrum through biopsy. The study subjects were comprised of 22 (61.11\%) male and $14(38.89 \%)$ female subjects between the ages of 25 and 82 years. Clinical diagnosis of the study participants included gastritis, gastric ulcer, and gastric neoplasms.

The experimental study was conducted using a random group approach with CagA protein structure as the dependent variable and gastric mucosal injury as the independent variable. Gastric pathology was categorized into three types of disease, including: Gastritis, gastric/duodenal ulcer, and gastric carcinoma. The samples were divided into equal proportions for each pathologic condition.

Subcultures of $H$. pylori Bali isolates were obtained from cultures of gastric biopsy specimens of gastric body, antrum, and pylorus of patients presenting with dyspepsia symptoms to the Internal Medicine Outpatient Clinic of Sanglah Central Hospital. H. pylori isolates $(\mathrm{n}=36)$ were stored in Trypticase Soy Broth medium with $10 \%$ glycerol at $-80^{\circ} \mathrm{C}$ at Biomedical Research Unit Laboratory, West Nusa Tenggara Regional Hospital. H. pylori was subsequently subcultured using Trypticase Soy Agar medium supplemented with $10 \%$ sheep's blood, 2 $\mathrm{mL} / 500 \mathrm{~mL}$ Dent medium and $10 \mathrm{~mL} / 500 \mathrm{~mL}$ Vitox. The culture was then incubated in a $\mathrm{CO}_{2}$ incubator to produce microaerophilic environment with $5 \% \mathrm{O}_{2}$, $10 \% \mathrm{CO}_{2}$, and $85 \% \mathrm{~N}_{2}$ for $48 \mathrm{~h}$ at $37^{\circ} \mathrm{C}$ temperature.

\section{DNA extraction}

DNA extractions of bacterial cells were prepared for purification using DNAzol reagent (Invitrogen ${ }^{\circledR}$ ). Approximately $1 \times 10^{9}$ cells in $1 \mathrm{~mL}$ were centrifuged at $10,000 \mathrm{rpm}$ for $5 \mathrm{~min}$, and the supernatant was then removed. Five hundred microliters of DNAzol reagent was inverted 10 times and then vortexed at $200 \mathrm{rpm}$ for $2 \mathrm{~min}$. This sample was centrifuged at $10,000 \mathrm{rpm}$ for $10 \mathrm{~min}$; and the supernatant was transferred to a new sterile tube. Five hundred microliters of absolute ethanol solution were added to the supernatant, and the mixture was subsequently incubated at room temperature for 3 min, followed by mixing of the inversion portion and centrifugation at $4000 \mathrm{rpm}$ for $5 \mathrm{~min}$. The supernatant was carefully removed, and the remaining pellet was washed twice with $80 \%$ ethanol. The pellet was resuspended with either $50 \mu \mathrm{L} \mathrm{dd}_{2} \mathrm{O}$ or $8 \mathrm{mM} \mathrm{NaOH}$ solution.

\section{Amplification and sequencing of CagA DNA}

Genomic DNA extraction was performed using the DNAZol Kit(Invitrogen, Thermo Fisher Scientific, California, US), according to the manufacturer's instructions. The amplification of the $\operatorname{Cag} A 3^{\prime}$ variable region was carried out using the primers P1 (5'GA TAACAGGCAAGCTTTTTGAGG-3') and P2 (5'CTGCAAAAGATTGTTTGGCAG-3') (18). The amplification steps were conducted under the following conditions: $94^{\circ} \mathrm{C}$ for $1 \mathrm{~min} ; 34$ cycles of $94^{\circ} \mathrm{C}$ for $1 \mathrm{~min}$, 
and $55^{\circ} \mathrm{C}$ for $1 \mathrm{~min}$, followed by $72^{\circ} \mathrm{C}$ for $1 \mathrm{~min}$; with a final extension at $72^{\circ} \mathrm{C}$ for $5 \mathrm{~min}$. The solutions were then stored at $4^{\circ} \mathrm{C}$. PCR products were separated by $2 \%$ agarose gel electrophoresis and examined under ultraviolet illumination, then sequenced. The data presented as sequences either resulting from the sequencing process or downloaded from GenBank were analyzed using BioEdit and MEGAv7 software [20]. The phylogenetic tree was constructed using a maximum likelihood algorithm on $36 \mathrm{CagA}$ sequences of Bali origin and eight isolate sequences obtained from neighboring countries downloaded from the GenBank.

\section{In silico analysis}

Three $C a g A$ fragments were chosen as representation of $H$. pylori Bali isolates - namely, W2, W9, and W35 fragments - which were modeled through threading modeling approach using I-TASSER, which is an online platform that can estimate the three-dimensional structure of a protein as well as predict its function. The three-dimensional model of the targeted protein generated by the I-TASSER server results from a combination of the predictions obtained from the multiple-threading alignment process. The prediction result of the model is chosen based on the confidence score (c-score) [21]. Subsequently, the model was reconstructed using ModRefiner to obtain a reliable model, the quality of which was then assessed based on a Ramachandran Plot as analyzed using RAMPAGE. Meanwhile, the SHP2 (PDBID: 2SHP) model was obtained using experimental X-ray diffraction with $2 \mathrm{~A}$ resolution which was downloaded from the Protein Data Bank. Then SHP2 was modeled as a receptor with the Lom fragment serving as ligand, both of which subsequently underwent docking using PATCHDOCK [22]. This docking process was conducted rigidly and was followed by the refinement process of flexible docking using FIREDOCK. The flexibly conducted docking process followed actual conditions or used induced fit interaction principles. Docking was performed blind as the binding site of the ligand on the receptor remained unknown. The resulting model was chosen based on that with the most negative binding energy, as the more negative the binding energy, the higher the affinity of the ligand toward its receptor.

\section{Statistical analysis}

The data were analyzed using SPSS program for Windows version 24 (IBM Corp., NY, USA). Discrete variables were tested using a Chi-square test, whereas continuous variables were tested using the MannWhitney U- and t-tests [23]. A two-tailed $\mathrm{p}<0.05$ was considered statistically significant [24]. Data for the CagA C-terminal structure patterning and SHP2 binding intensity were analyzed using non-parametric analysis.

\section{Results}

\section{Baseline characteristics of study population}

In this study, 12 (33.3\%) participants tested positive for CagA protein. The results of the endoscopic studies conducted on study participants showed a variety of gastric pathology, including: Antral superficial gastritis in $21(58.33 \%)$, antral erosive gastritis in $7(19.44 \%)$, antral chronic gastritis in $2(5.55 \%)$, superficial gastritis involving gastric fundus and corpus in 1 $(2.78 \%)$, erosive gastritis involving gastric corpus and antrum in $1(2.78 \%)$, duodenal ulcer in $1(2.78 \%)$, suspected gastric malignancy in $1(2.78 \%)$, erosive gastritis of the gastric corpus in $1(2.78 \%)$, and superficial gastritis involving gastric antrum and corpus in $1(2.78 \%)$. To simplify, the proportion of study participants exhibiting gastric pathology are as follows: Gastritis in 34 (94.44\%), duodenal ulcer in $1(2.78 \%)$, and gastric malignancy in 1 (2.78\%) (Table-1 and Figures-1-5).

\section{PCR of CagA genes}

From 20 biopsy tissues within paraffin blocks and 30 specimens obtained from gastric mucosa biopsy, 12 specimens tested positive for CagA using PCR which included several genes, namely: M1334.17, M1499.17, M1606.17, and M1858.17 (hereafter referred to as W1, W2, W3, and W12) (Figure-6).

\section{Discussion}

The prevalence of positive CagA results was $33.33 \%$ of the 36 study participants, with the

Table-1: Demographic characteristics of study participants.

\begin{tabular}{lc}
\hline Variable & $\mathbf{n}(\%)$ \\
\hline Sex & \\
Male & $22(61.11)$ \\
Female & $14(38.89)$ \\
Age group & \\
$\leq 29$ & $5(13.89)$ \\
$30-39$ & $3(8.33)$ \\
$40-49$ & $10(27.78)$ \\
$50-59$ & $12(33.33)$ \\
$60-69$ & $4(11.11)$ \\
$70-79$ & $1(2.78)$ \\
$80-89$ & $1(2.78)$ \\
Demographic background & \\
Denpasar & $15(41.67)$ \\
Gianyar & $4(11.11)$ \\
Tabanan & $1(2.78)$ \\
Badung & $5(13.89)$ \\
Karangasem & $3(8.33)$ \\
Negara & $1(2.78)$ \\
Buleleng & $3(8.33)$ \\
Bangli & $1(2.78)$ \\
Klungkung & $1(2.78)$ \\
Manggarai & $1(2.78)$ \\
Endoscopic features & \\
Antral superficial gastritis & $21(58.33)$ \\
Antral erosive gastritis & $7(19.44)$ \\
Antral chronic gastritis & $2(5.55)$ \\
Superficial gastritis involving gastric & $1(2.78)$ \\
fundus and corpus & \\
Erosive gastritis involving gastric corpus & $1(2.78)$ \\
and antrum & \\
Duodenal ulcer & $1(2.78)$ \\
Suspected gastric malignancy & $1(2.78)$ \\
Erosive gastritis of gastric corpus & $1(2.78)$ \\
Superficial gastritis involving gastric & $1(2.78)$ \\
corpus and antrum & \\
\hline & \\
\hline & \\
\hline & \\
\hline
\end{tabular}




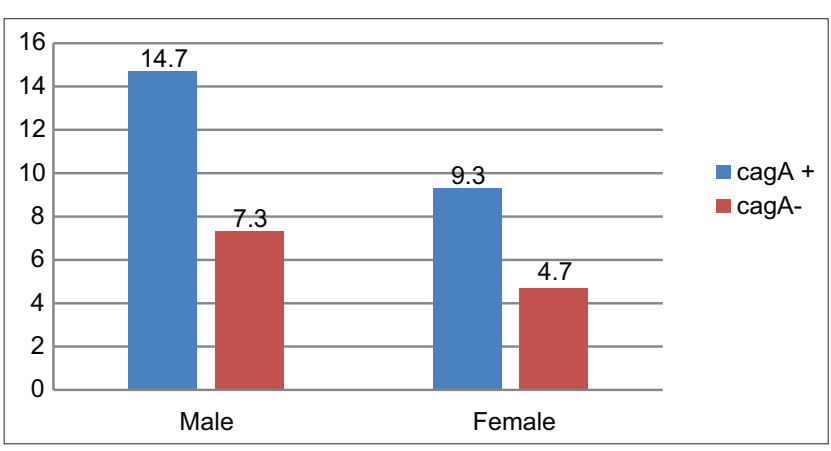

Figure-1: Comparison of cytotoxic associated antigen $A$ testing results based on sex; $p=0.003$, with Fisher's exact test $=0.003$, and an alpha value of 0.05 and probability of $90.0 \%$.

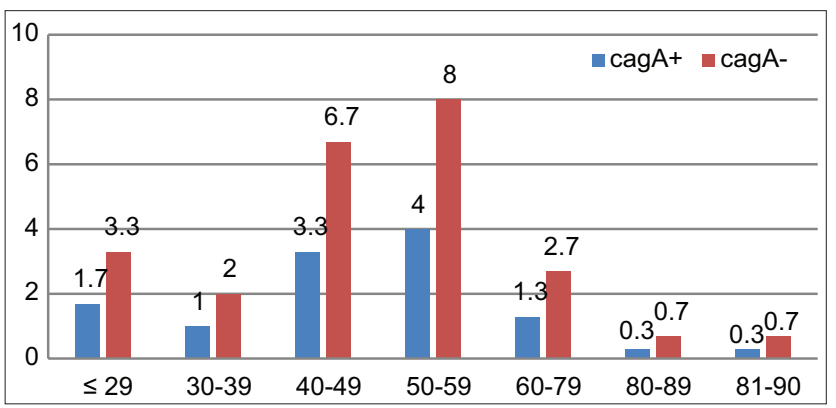

Figure-2: Comparison of cytotoxic associated antigen $A$ testing results based on age group; $p=0.136$, with Fisher's exact test $=0.142$, and an alpha value of 0.05 , and probability of $90.0 \%$.

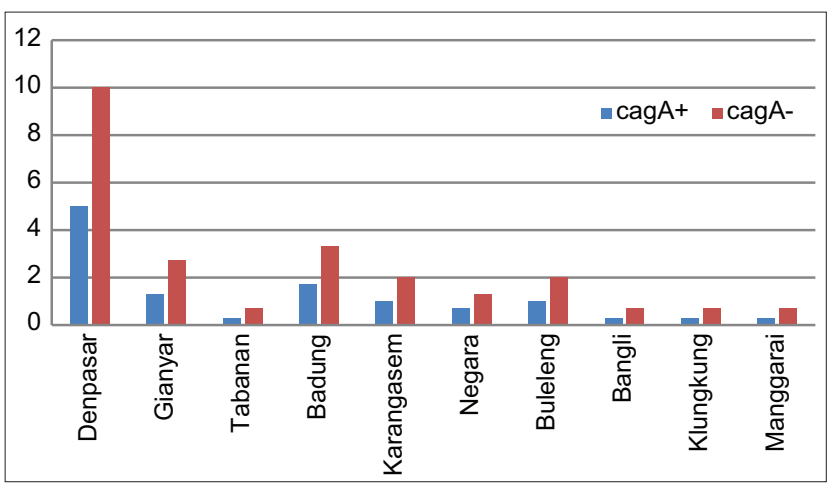

Figure-3: Comparison of cytotoxic associated antigen A testing results based on demographic background; $p=0.937$, with fisher exact test $=0.951$ and alpha value of 0.05 and probability of $90.0 \%$.

prevalence in men (61.11\%) being significantly higher than in women $(38.89 \%)$ (Table-1). These results are in accordance with a previous study conducted by Kaore et al. [25], which also showed a higher prevalence in men compared to women. The results indicated a very significant association between sex and prevalence of CagA-positive H. pylori infection with $\mathrm{p}=0.003$. These data, therefore, indicate that CagApositive infection is influenced by gender differences (Figure-1).

The mean age of the infected patients was in the range of 50-59 years. There was no significant association between age group and CagA-positive infection. The lowest infection prevalence was found among

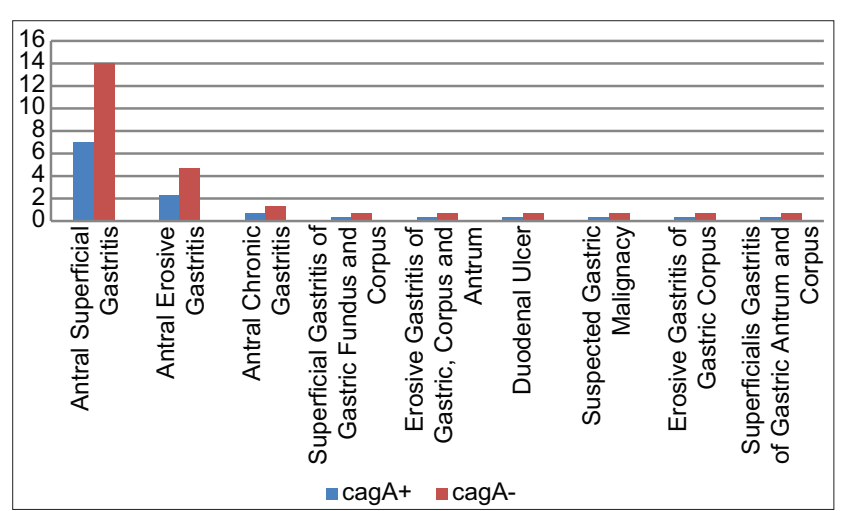

Figure-4: Comparison of cytotoxic associated antigen $A$ testing results based on the results of endoscopic study; $\mathrm{p}=0.663$, with Fisher's exact test result $=0.672$ and alpha value of 0.05 and probability of $90.0 \%$.

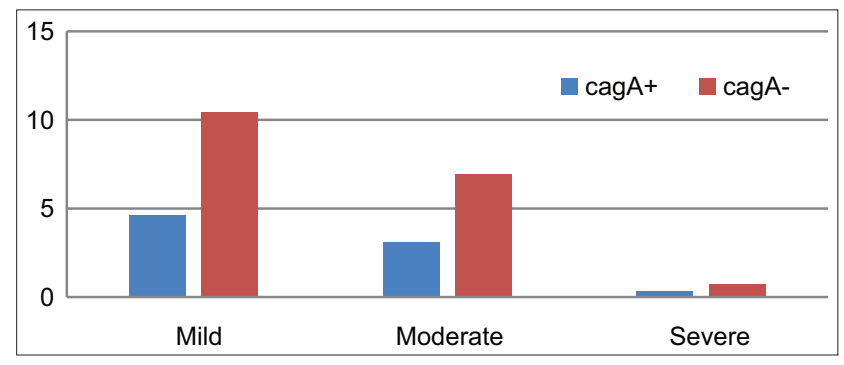

Figure-5: Comparison of cytotoxic associated antigen A testing results based on the degree of inflammation; $p=0.769$, with Fisher's exact test result of 0.769 and alpha value of 0.05 and probability of $90.0 \%$.

patients in the 70-79 and 80-89 years age groups $(2.78 \%)$ (Figure-2). Based on the study conducted by Lamichhane et al. [26], incidence of $H$. pylori decreases at ages $>60$ years old. The results indicated no significant association between age and $H$. pylori infection. However, another study conducted in a different population showed a higher proportion of $H$. pylori infection among those aged $<29$ years and those within the 50-59 years of age group [27]. These results are also supported by other research that found a similar tendency of the rates of $H$. pylori infection among individuals aged $>40$ years [28]. In general, the prevalence of $H$. pylori infection throughout different time periods is $74.7 \%, 53.0 \%$, and $35.1 \%$ in the 1970s, 1990s, and 2010s, respectively [29].

Here, the prevalence of CagA-positive H. pylori infection in Denpasar, Bali was higher when compared to other areas at $41.67 \%$ (15 patients). The relationship between demographic background and CagA-positive infection was statistically not significant with $p=0.769$. Thus, these results indicate that demographic characteristics do not influence the occurrence of $H$. pylori infection (Figure-3).

In this study, we found gastritis to be the most commonly detected gastric pathology $(94.4 \%)$. The association between endoscopic results and CagApositive infection was statistically insignificant with $\mathrm{p}=0.663$, thus indicating that the theory of endoscopic alteration as being a sensitive indicator of $H$. pylori 
infection remains unelucidated (Figure-4). Another study also implicated gastritis $(69.0 \%)$ as the most common gastric pathology detected during $H$. pylori infection [30]. Correlation between endoscopic alteration and $H$. pylori infection was statistically significant with $\mathrm{p}<0.01$, indicating that endoscopic alteration could be used as a sensitive indicator for predicting H. pylori infection [31].

Amajority of the study participants exhibited mild gastric inflammation. The relationship between the degree of inflammation and CagA-positive infection was not statistically significant $(\mathrm{p}=0.769)$ (Figure-5). A previous study described 35 (67.31\%) patients had acute inflammation, which was comprised 29 (83\%) mild, 5 (14\%) moderate, and $1(3 \%)$ severe inflammation. Meanwhile, $51(98.08 \%)$ patients were found to have chronic inflammation, of which $2(4 \%)$ exhibited mild, 14 (27\%) moderate, and $35(69 \%)$ severe inflammation. H. pylori infection was detected in 30 patients, with $3(10 \%)$ presenting with mild, $6(20 \%)$ with moderate, and 21 (70\%) with severe disease [32].

\section{Variation of CagA protein}

According to the phylogenetic analyses and the 12 CagA sequences obtained herein, it can be concluded that the $H$. pylori strain of Bali can be grouped within the East Asian genotypes and is identical to Lombok strain (Figure-6). In addition, these Bali isolates are phylogenetically more closely related to Southeast Asian strains of the bacteria, particularly the Filipino strain. From the phylogenetic tree, the cluster representing the $H$. pylori Bali strain is shown far from the East Asian cluster.

The H. pylori strain from Bali also contained an EPIYA amino acid coding motif within the $C a g A$ gene that underwent substitution of its amino acids from

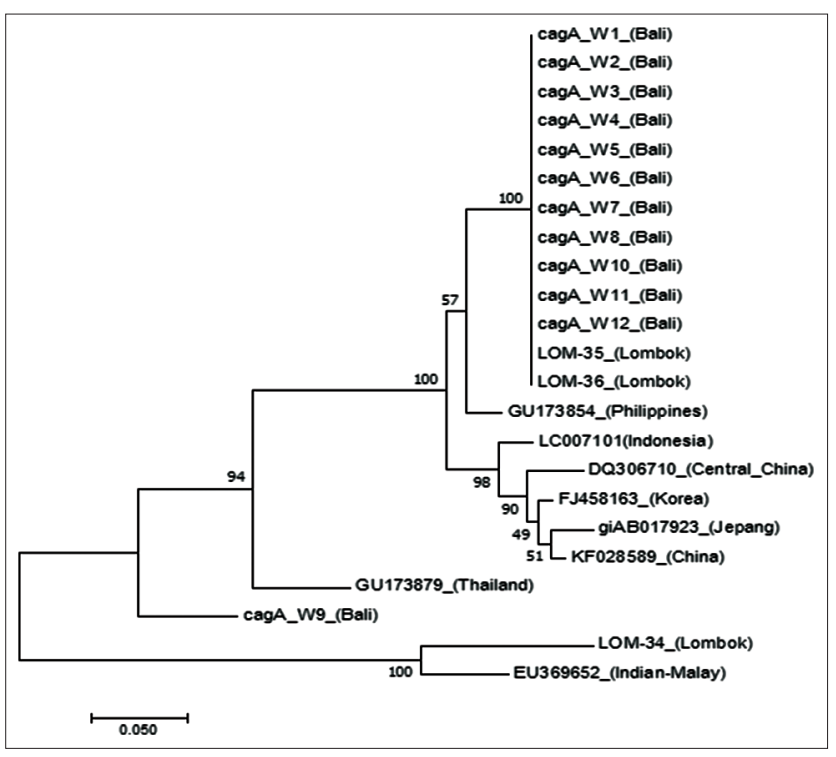

Figure-6: Phylogenetic tree built using maximum likelihood (ML) algorithm from cytotoxic associated antigen A genes of Helicobacter pylori Bali isolates (W1 to W12), H. pylori Lombok isolates (LOM34, LOM35, and LOM36), as well as $H$. pylori from several Asian countries. The numbers on the branches represent the percentage of bootstrap used.
A to $\mathrm{T}$, hence, transforming it into an EPIYT motif (Figure-7). This EPIYT motif is suspected to be more virulent and increases the risk of developing cancer $[33,34]$. CagA-positive $H$. pylori infection induces alteration of inflammation levels of gastric mucosa, which in turn eventually can cause gastric cancer, superficial gastritis, atrophic gastritis, intestinal metaplasia, dysplasia, and carcinoma [35].

This study employed PCR using DNA from corpus and antral tissues to detect CagA protein. As mentioned, the prevalence of CagA-positive results found here was $33.3 \%$. A previous study found similar results with $32 \%$ of gastric cancer patients being CagA-positive [36]. A Japanese group that also used PCR as their confirmatory modality found $31.6 \%$ CagA-positive cases from 57 gastric cancer tissues [37]. Meanwhile, a study conducted in South Korea also showed a high prevalence of CagApositive cases [38]. Overall, it was found that $22.4 \%$ $(\mathrm{n}=37 / 165)$ patients were infected with CagA-positive H. pylori strains and $77.6 \%(\mathrm{n}=128 / 165)$ patients were infected with a CagA-negative strain [29].

Two primary forms of CagA protein have been identified: East Asian and Western. In East Asian countries - such as Japan, South Korea, and China

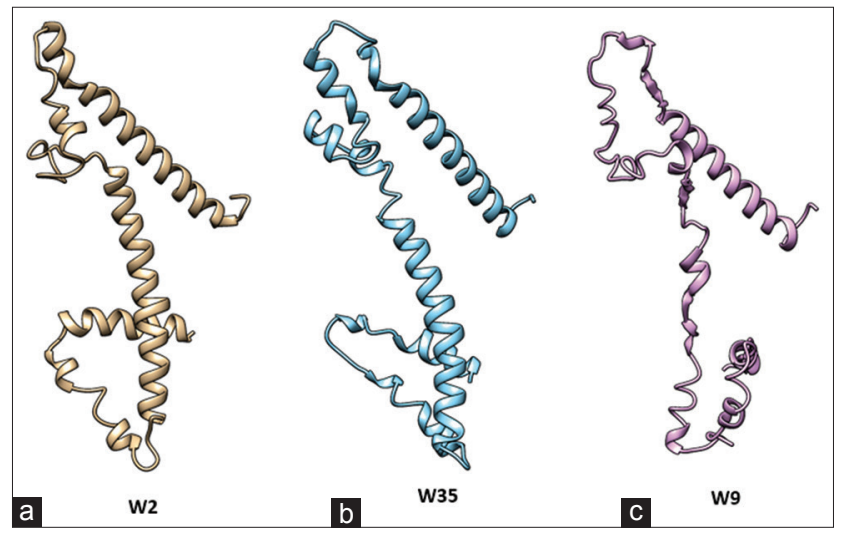

Figure-7: Prediction of protein structure of the C-terminal cytotoxic associated antigen A fragment of Helicobacter pylori Bali isolates. (a) W2 fragment with the EPIYA-ABD (East Asian) motif in patient with gastric cancer; (b) W35 fragment with EPIYA-ABD (East Asian) motif in gastritis patients; and (c) W9 fragment with EPIYA ABC (Western) motif.

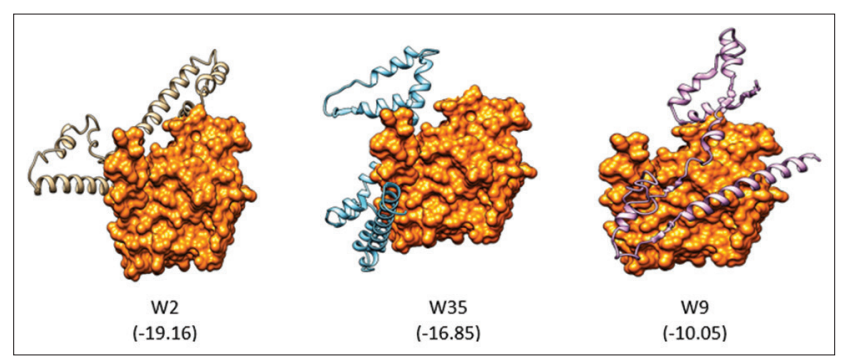

Figure-8: In silico analysis for the interaction between C-terminus of the cytotoxic associated antigen A protein fragment and SHP2. The numbers in the bracket represent free energy binding. The more negative the free energy binding, the stronger the binding between a ligand and its receptor. 
- most H. pylori infections were of the East Asian CagA strain. Level of inflammation, gastritis activity, and atrophy was significantly higher among patients infected with the CagA-positive East Asian strain as compared to those infected with CagA-negative East Asian or CagA-positive Western strains [39].

As the most relevant virulence factor of $H$. pylori, CagA interferes with cellular function through physical interaction and intracellular signal deregulation both through dependent tyrosine phosphorylation and an independent mechanism after its delivery to gastric epithelial cells [40]. After being translocated into the host cytoplasm, CagA binds the surface of the cell membrane and undergoes tyrosine phosphorylation. The phosphorylated and unphosphorylated forms of CagA interact with a host protein to activate downstream signaling pathways, such as induction of ornithine decarboxylase upregulation through the $\mathrm{Src} /$ MEK/ERK/c-Myc pathway [41] and trafficking of REG3 $\gamma$ within gastric epithelial cells by activation of the interleukin (IL)-11/gp130/STAT3 pathway [42]. Non-phosphorylated CagA protein can activate hepatocyte growth factor/c-Met receptor scatter factor and adaptor Grb2 protein, induce phosphorylation of gamma phospholipase $\mathrm{C}$ and impair formation of $\mathrm{e}$-cadherin/b-catenin formation, and affect inhibition of polarity-regulating kinase partitioning-defective $1 \mathrm{~b} /$ microtubules kinase- 2 to interfere with the atypical signaling pathway of protein kinase $\mathrm{C}$.

Experiments with transgenic zebrafish revealed the wild-type and phosphorylation-resistant forms of CagA that showed significantly increased intestinal epithelial proliferation and upregulation of several target genes: Wnt cyclinD1, axin2, and zebrafish c-myc ortholog myca [43]. In addition, CagA was also found to induce higher production of IL-8, nuclear factor $\kappa B(N F-\kappa B)$, activator protein-1 and fatty acid dislocase (FAT) activities [44] and increased the activity of transforming growth factor beta-activated kinase 1 (TAK1) and KIA-mediated induction of TAK1-NF- $\kappa B$ that was associated with KIA and also connected to TPA1, which is eventually utilized by the CagA protein of $H$. pylori to induce an inflammatory response [45]. This might also inhibit miR370 expression, which can lead to overexpression of FoxM1 and subsequently increase intestinal cell proliferation [46]. These findings implicated some important roles of CagA in gastric carcinogenesis. In silico analysis showed that CagA protein with an EPIYA-ABD motif exhibits stronger affinity toward SHP2 (Figure-8).

\section{Conclusion}

The H. pylori Bali strain consists of the East Asia genotype and possesses identical characteristics of the Lombok strain. In addition, Bali isolates are phylogenetically more closely related to Southeast Asian strains of the bacteria, in particular the Filipino strain. From the phylogenetic tree, it is shown that the H. pylori strain cluster of Bali origin is distant from the East Asian cluster.

\section{Authors' Contributions}

HS: Designed the research, lab work, analyze the data, and writing the manuscript; DNW: Designed the research, sample collection, laboratory work, analyze the data, and writing the manuscript; ZM: Sample collection, laboratory work, analyzed the data, and writing the manuscript; KKA: Sample collection, laboratory work, analyze the data, and writing the manuscript. All authors read and approved the final manuscript.

\section{Acknowledgments}

The authors are thankful to Rector of Udayana University, Indonesia, for funding and supporting this research through Group Research Grant with contract No. 673-17/UN14.4A/LT/2017.

\section{Competing Interests}

The authors declare that they have no competing interests.

\section{Publisher's Note}

Veterinary World remains neutral with regard to jurisdictional claims in published institutional affiliation.

\section{References}

1. Warren, J.R. and Marshall, B.J. (1983) Unidentified curved bacilli on gastric epithelium in active chronic gastritis. Lancet, 1(8336): 1273-1275.

2. Solnick, J.V. and Schauer, D.B. (2001) Emergence of diverse Helicobacter species in the pathogenesis of gastric and enterohepatic diseases. Clin. Microbiol. Rev., 14(1): 59-97.

3. Suharsono, H., Muttaqin, Z., Tenaya, I.W.M., Agustina, K.K. and Prawiro, S.R. (2019) Antigen of 49.6-kDa sub unit pili protein of Helicobacter pylori as a potential biomarker for early and rapid detection of the infection. Vet. World, 12(6): 769-773.

4. Bridge, D.R. and Merrell, D.S. (2013) Polymorphism in the Helicobacter pylori CagA and VacA toxins and disease. Gut Microbes, 4(2): 101-117.

5. Syam, A.F., Miftahussurur, M., Makmun, D., Nusi, I.A., Zain, L.H., Zulkhairi, Akil, F., Uswan, W.B., Simanjuntak, D., Uchida, T.,Adi,P., Utari,A.P., Rezkitha, Y.A.A., Subsomwong, P., Nasronudin, Suzuki, R. and Yamaoka, Y. (2015) Risk factors and prevalence of Helicobacter pylori in five largest islands of Indonesia: A preliminary study. PLoS One, 10(11): e0140186.

6. Soemohardjo, S., Wenny, A. and Muttaqin, Z. (1993) Penelitian epidemiologi infeksi Helicobacter pylori di Mataram. Dexa Media, 3(6): 9-12.

7. Soemohardjo, S., Palgunadi, I.G., Gunawan, G. and Muttaqin, Z. (2007) Deteksi Helicobacter pylori Pada Spesimen Biopsi Mukosa Lambung Menggunakan Primer ureC. Puslitbang Biologi, Bogor. p1-4.

8. Yamaoka, Y. and Miftahussurur, M. (2017) Helicobacter pylori virulence genes and host genetic polymorphisms as risk factors for peptic ulcer disease. Expert Rev. Gastroenterol. Hepatol., 9(12): 1535-1547.

9. Wang, L., Dong, K., Zhan, S., Dong, Q., Huang, J., Zhou, J. and Yu, X. (2014) Association of virulent genotypes and phylogenetic origins of Helicobacter pylori with gastric cancer. J. Int. Med. Res., 42(4): 898-905.

10. Van Doorn, L.J., Schneeberger, P.M., Nouhan, N., Plaisier, A.P., Quint, W.G.V. and De Boer, W.A. (2000) 
Importance of Helicobacter pylori cagA and vacA status for the efficacy of antibiotic treatment. Gut, 46(3): 321-326.

11. Tomb, J.F., White, O., Kerlavage, A.R., Clayton, R.A., Sutton, G.G., Fleischmann, R.D., Ketchum, K.A., Klenk, H.P., Gill, S., Dougherty, B.A., Nelson, K., Quackenbush, J., Zhou, L., Kirkness, E.F., Peterson, S., Loftus, B., Richardson, D., Dodson, R., Khalak, H.G., Glodek,A.,McKenney,K.,Fitzegerald,L.M.,Lee,N.,Adams,M.D., Hickey, E.K., Berg, D.E., Gocayne, J.D., Utterback, T.R., Peterson, J.D., Kelley, J.M., Cotton, M.D., Weidman, J.M., Fujii, C., Bowman, C., Watthey, L., Wallin, E., Hayes, W.S., Borodovsky, M., Karp, P.D., Smith, H.O., Fraser, C.M. and Venter, J.C. (1997) The complete genome sequence of the gastric pathogen Helicobacter pylori. Nature, 388(9): 539-547.

12. Roesler, B.M., Rabelo-Gonçalves, E.M.A. and Zeitune, J.M.R. (2014) Clinical medicine insights: Gastroenterology virulence factors of Helicobacter pylori: A review. Clin. Med. Insights Gastroenterol., 7(3): 9-17.

13. Jones, K.R., Whitmire, J.M. and Merrell, D.S. (2010) A tale of two toxins: Helicobacter pylori CagA and VacA modulate host pathways that impact disease. Front. Microbiol., 1(115): 1-17.

14. Covacci, A., Censini, S., Bugnoli, M., Petracca, R., Burroni, D., Macchia, G., Massone, A., Papini, E., Xiang, Z., Figura, N. and Rappuoli, R. (1993) Molecular characterization of the $128-\mathrm{kDa}$ immunodominant antigen of Helicobacter pylori associated with cytotoxicity and duodenal ulcer. Proc. Natl. Acad. Sci. U. S. A., 90(12): 5791-5795.

15. Kusters, J.G., van Vliet, A.H.M. and Kuipers, E.J. (2006) Pathogenesis of Helicobacter pylori infection. Clin. Microbiol. Rev., 19(3): 449-490.

16. Haddadi, M.H., Bazargani, A., Khashei, R., Fattahi, M.R., Lankarani, K.B., Moini, M. and Hosseini, S.M.H. (2015) Different distribution of Helicobacter pylori EPIYA cagA motifs and dupA genes in the upper gastrointestinal diseases and correlation with clinical outcomes in Iranian patients. Gastroenterol. Hepatol. Bed Bench, 8(1): S37-546.

17. Miftahussurur, M., Tuda, J., Suzuki, R., Kido, Y., Kawamoto, F., Matsuda, M., Tantular, I.S., Pusarwati, S., Nasronudin, Harijanto, P.N. and Yamaoka, Y. (2014) Extremely low Helicobacter pylori prevalence in North Sulawesi, Indonesia and identification of a Maori-tribe type strain: A cross-sectional study. Gut Pathog., 6(1): 1-8.

18. Muttaqin, Z., Suharjono, and Aulanni'am, A. (2016) Phylogenetic analysis of 3' region of Helicobacter pylori cagA gene of Lombok isolates and the association with gastric pathology. IOSR J. Pharm. Biol. Sci., 11(1): 1-6.

19. Nagase, L., Murata-Kamiya, N. and Hatakeyama, M. (2011) Potentiation of Helicobacter pylori CagA protein virulence through homodimerization. J. Biol. Chem., 286(38): 33622-33631.

20. Kumar, S., Stecher, G. and Tamura, K. (2016) MEGA7: Molecular evolutionary genetics analysis version 7.0 for bigger datasets. Mol. Biol. Evol., 33(7): 1870-1874.

21. Khor, B.Y., Tye, G.J., Lim, T.S., Noordin, R. and Choong, Y.S. (2014) The structure and dynamics of BmR1 protein from Brugia malayi: In silico approaches. Int. J. Mol. Sci., 15(6): 11082-11099.

22. Schneidman-Duhovny, D., Nussinov, R. and Wolfson, H.J. (2004) Predicting molecular interactions in silico: II. protein-protein and protein-drug docking. Front. Med. Chem., 11(1): 585-613.

23. Fay, M.P. and Proschan, M.A. (2010) Wilcoxon-mannwhitney or t-test? On assumptions for hypothesis tests and multiple interpretations of decision rules. Stat. Surv., 4(4): $1-39$.

24. Dahiru, T. (2008) P-Value, a true test of statistical significance? A cautionary note. Ann. Ib. Postgrad. Med., 6(1): 21-26.

25. Kaore, N.M., Nagdeo, N.V. and Thombare, V.R. (2012) Comparative evaluation of the diagnostic tests for
Helicobacter pylori and dietary influence for its acquisition in dyspeptic patients: A rural hospital based study in central India. J. Clin. Diagn. Res., 6(4 Suppl 2): 636-641.

26. Lamichhane, A., Azegami, T. and Kiyono, H. (2014) The mucosal immune system for vaccine development. Vaccine, 32(49): 6711-6723.

27. Miftahussurur, M., Syam, A.F., Makmun, D., Nusi, I.A., Uchida, T., Suzuki, R. and Yamaoka, Y. (2015) Su1926 prevalence and virulence factors characteristics of Helicobacter pylori infection in five largest Islands in Indonesia. Gastroenterology, 148(4): S-553.

28. Kamada, T., Haruma, K., Ito, M., Inoue, K., Manabe, N., Matsumoto, H., Kusunoki, H., Hata, J., Yoshihara, M., Sumii, K., Akiyama, T., Tanaka, S., Shiotani, A. and Graham, D.Y. (2015) Time trends in Helicobacter pylori infection and atrophic gastritis over 40 years in Japan. Helicobacter, 20(3): 192-198.

29. Brennan, D.E., Dowd, C., O'Morain, C., McNamara, D. and Smith, S.M. (2018) Can bacterial virulence factors predict antibiotic-resistant Helicobacter pylori infection? World J. Gastroenterol., 24(9): 971-981.

30. Roesler, B.M. and Zeitune, J.M.R. (2012) From gastritis to gastric cancer: The importance of CagPAI of Helicobacter pylori on the development of early and advanced gastric adenocarcinoma. In: Current Topics in Gastritis. Intech Open, London. p223-240.

31. Adlekha, S., Chadha, T., Krishnan, P. and Sumangala, B. (2013) Prevalence of Helicobacter pylori infection among patients undergoing upper gastrointestinal endoscopy in a medical college hospital in Kerala, India. Ann. Med. Health Sci. Res., 3(4): 559-563.

32. Yulida, E., Oktaviyanti, I.K. and Rosida, L. (2013) Gambaran derajat infiltrasi sel radang dan infeksi Helicobacter pylori pada biopsi lambung pasien gastritis. Berk. Kedokt., 9(1): 51-65.

33. Wen, S. and Moss, S.F. (2009) Helicobacter pylori virulence factors in gastric carcinogenesis. Cancer Lett., 282(1): 1-8.

34. Deenonpoe, R., Mairiang, E., Mairiang, P., Pairojkul, C., Chamgramol, Y., Rinaldi, G., Loukas, A., Brindley, P.J. and Sripa, B. (2017) Elevated prevalence of Helicobacter species and virulence factors in opisthorchiasis and associated hepatobiliary disease. Sci. Rep., 7(42744): 1-11.

35. Correa, P. and Piazuelo, M.B. (2011) Helicobacter pylori infection and gastric adenocarcinoma pelayo. $U . S$. Gastroenterol. Hepatol. Rev., 7(1): 59-64.

36. Zhang, Y.W., Eom, S.Y., Yim, D.H., Song, Y.J., Yun, H.Y., Park, J.S., Youn, S.J., Kim, B.S., Kim, Y.D. and Kim, H. (2013) Evaluation of the relationship between dietary factors, CagA-positive Helicobacter pylori infection, and RUNX3 promoter hypermethylation in gastric cancer tissue. World J. Gastroenterol., 19(11): 1778-1787.

37. Kitajima, Y., Ohtaka, K., Mitsuno, M., Tanaka, M., Sato, S., Nakafusa, Y. and Miyazaki, K. (2008) Helicobacter pylori infection is an independent risk factor for Runx3 methylation in gastric cancer. Oncol. Rep., 19(1): 197-202.

38. Shiota, S., Matsunari, O., Watada, M. and Yamaoka, Y. (2010) Serum Helicobacter pylori CagA antibody as a biomarker for gastric cancer in east-Asian countries. Future Microbiol., 5(12): 1885-1893.

39. Correa, P., Haenszel, W., Cuello, C., Tannenbaum, S. and Archer, M. (1975) A model for gastric cancer epidemiology. Lancet, 2(7924): 58-60.

40. Liu, Z., Xu, X., Chen, L., Li, W., Sun, Y., Zeng, J., Yu, H., Chen, C. and Jia, J. (2012) Helicobacter pylori CagA inhibits the expression of Runx3 Via Src/MEK/ERK and p38 MAPK pathways in gastric epithelial cell. J. Cell Biochem., 113(3): 1080-1086.

41. Xu, X., Liu, Z., Fang, M., Yu, H., Liang, X., Li, X., Liu, X., Chen, C. and Jia, J. (2012) Helicobacter pylori CagA induces ornithine decarboxylase upregulation via $\mathrm{Src} / \mathrm{MEK} / \mathrm{ERK} / \mathrm{c}-\mathrm{Myc}$ pathway: Implication for 
progression of gastric diseases. Exp. Biol. Med., 237(4): 435-441.

42. Lee, K.S., Kalantzis, A., Jackson, C.B., O’Connor, L., MurataKamiya, N., Hatakeyama, M., Judd, L.M., Giraud, A.S. and Menheniott, T.R. (2012) Helicobacter pylori CagA triggers expression of the bactericidal lectin REG3 $\gamma$ via gastric STAT3 activation. PLoS One, 7(2): e30786.

43. Neal, J.T., Peterson, T.S., Kent, M.L. and Guillemin, K. (2013) H. pylori virulence factor CagA increases intestinal cell proliferation by Wnt pathway activation in a transgenic zebrafish model. Dis. Model. Mech., 6(3): 802-810.

44. Fazeli, Z., Alebouyeh, M., Tavirani, M.R., Azimirad, M. and
Yadegar, A. (2016) Helicobacter pylori CagA induced interleukin-8 secretion in gastric epithelial cells. Gastroenterol. Hepatol. Bed Bench, 9(Suppl 1): S42-S46.

45. Lamb, A., Yang, X.D., Tsang, Y.H.N., Li, J.D., Higashi, H., Hatakeyama, M., Peek, R.M., Blanke, S.R. and Chen, L.F. (2009) Helicobacter pylori CagA activates NF-KB by targeting TAK1 for TRAF6-mediated Lys 63 ubiquitination. EMBO Rep., 10(11): 1242-1249.

46. Feng, Y., Wang, L., Zeng, J., Shen, L., Liang, X., Yu, H., Liu, S., Liu, Z., Sun, Y., Li, W., Chen, C. and Jia, J. (2013) FoxM1 is overexpressed in Helicobacter pylori induced gastric carcinogenesis and is negatively regulated by miR370. Mol. Cancer Res., 11(8): 834-844.

$* * * * * * * *$ 